\title{
Cytochrome P450 in GtoPdb v.2021.2
}

\author{
Kathryn Burns ${ }^{1}$ and Nuala Ann Helsby ${ }^{1}$
}

1. University of Auckland, New Zealand

\begin{abstract}
The cytochrome P450 enzyme superfamily (CYP), E.C. 1.14.---, are haem-containing monooxygenases with a vast range of both endogenous and exogenous substrates. These include sterols, fatty acids, eicosanoids, fat-soluble vitamins, hormones, pesticides and carcinogens as well as drugs. Listed below are the human enzymes, their relationship with rodent CYP enzyme activities is obscure in that the species orthologue may not metabolise the same substrates. Some of the CYP enzymes located in the liver are particularly important for drug metabolism, both hepatic and extrahepatic CYP enzymes also contribute to patho/physiological processes. Genetic variation of CYP isoforms is widespread and likely underlies a proportion of individual variation in drug disposition. The superfamily has the root symbol CYP, followed by a number to indicate the family, a capital letter for the subfamily with a numeral for the individual enzyme. Some CYP are able to metabolise multiple substrates, others are oligo- or mono- specific.
\end{abstract}

\section{Contents}

This is a citation summary for Cytochrome P450 in the Guide to Pharmacology database (GtoPdb). It exists purely as an adjunct to the database to facilitate the recognition of citations to and from the database by citation analyzers. Readers will almost certainly want to visit the relevant sections of the database which are given here under database links.

GtoPdb is an expert-driven guide to pharmacological targets and the substances that act on them. GtoPdb is a reference work which is most usefully represented as an on-line database. As in any publication this work should be appropriately cited, and the papers it cites should also be recognized. This document provides a citation for the relevant parts of the database, and also provides a reference list for the research cited by those parts. For further details see [14].

Please note that the database version for the citations given in GtoPdb are to the most recent preceding version in which the family or its subfamilies and targets were substantially changed. The links below are to the current version. If you need to consult the cited version, rather than the most recent version, please contact the GtoPdb curators.

\section{Database links}

\author{
Cytochrome P450 \\ https://www.guidetopharmacology.org/GRAC/FamilyDisplayForward?familyId=242 \\ CYP1 family \\ https://www.guidetopharmacology.org/GRAC/FamilyDisplayForward?familyId=261 \\ Enzymes \\ CYP1A1 \\ https://www.guidetopharmacology.org/GRAC/ObjectDisplayForward?objectId=1318 \\ CYP1A2 \\ https://www.guidetopharmacology.org/GRAC/ObjectDisplayForward?objectId=1319 \\ CYP1B1 \\ https://www.guidetopharmacology.org/GRAC/ObjectDisplayForward?objectId=1320 \\ CYP2 family: drug metabolising subset \\ https://www.guidetopharmacology.org/GRAC/FamilyDisplayForward?familyId=262 \\ Enzymes \\ CYP2A6 \\ https://www.guidetopharmacology.org/GRAC/ObjectDisplayForward?objectId=1321
}


CYP2A7

https://www.guidetopharmacology.org/GRAC/ObjectDisplayForward?objectId=1322 CYP2A13

https://www.guidetopharmacology.org/GRAC/ObjectDisplayForward?objectId=1323 CYP2B6

https://www.guidetopharmacology.org/GRAC/ObjectDisplayForward?objectId=1324 CYP2C8

https://www.guidetopharmacology.org/GRAC/ObjectDisplayForward?objectId=1325 CYP2C9

https://www.guidetopharmacology.org/GRAC/ObjectDisplayForward?objectId=1326 CYP2C18

https://www.guidetopharmacology.org/GRAC/ObjectDisplayForward?objectId=1327 CYP2C19

https://www.guidetopharmacology.org/GRAC/ObjectDisplayForward?objectId=1328 CYP2D6

https://www.guidetopharmacology.org/GRAC/ObjectDisplayForward?objectId=1329 CYP2E1

https://www.guidetopharmacology.org/GRAC/ObjectDisplayForward?objectId=1330 CYP2F1

https://www.guidetopharmacology.org/GRAC/ObjectDisplayForward?objectId=1331 CYP2J2

https://www.guidetopharmacology.org/GRAC/ObjectDisplayForward?objectId=1332 CYP2 family: physiological enzymes subset

https://www.guidetopharmacology.org/GRAC/FamilyDisplayForward?familyId=1062

Enzymes

CYP2R1

https://www.guidetopharmacology.org/GRAC/ObjectDisplayForward?objectId=1333 CYP2S1

https://www.guidetopharmacology.org/GRAC/ObjectDisplayForward?objectId=1334 CYP2U1

https://www.guidetopharmacology.org/GRAC/ObjectDisplayForward?objectId=1335 CYP2W1

https://www.guidetopharmacology.org/GRAC/ObjectDisplayForward?objectId=1336

CYP3 family

https://www.guidetopharmacology.org/GRAC/FamilyDisplayForward?familyId=263

Enzymes

CYP3A4

https://www.guidetopharmacology.org/GRAC/ObjectDisplayForward?objectId=1337 CYP3A5

https://www.guidetopharmacology.org/GRAC/ObjectDisplayForward?objectId=1338 CYP3A7

https://www.guidetopharmacology.org/GRAC/ObjectDisplayForward?objectId=1339 CYP3A43

https://www.guidetopharmacology.org/GRAC/ObjectDisplayForward?objectId=1340

CYP4 family

https://www.guidetopharmacology.org/GRAC/FamilyDisplayForward?familyId=264

Enzymes

CYP4A11

https://www.guidetopharmacology.org/GRAC/ObjectDisplayForward?objectId=1341 CYP4A22

https://www.guidetopharmacology.org/GRAC/ObjectDisplayForward? objectId=1342 CYP4B1

https://www.guidetopharmacology.org/GRAC/ObjectDisplayForward?objectId=1343 CYP4F2

https://www.guidetopharmacology.org/GRAC/ObjectDisplayForward?objectId=1344 CYP4F3

https://www.guidetopharmacology.org/GRAC/ObjectDisplayForward?objectId=1345 CYP4F8

https://www.guidetopharmacology.org/GRAC/ObjectDisplayForward?objectId=1346 CYP4F11

https://www.guidetopharmacology.org/GRAC/ObjectDisplayForward?objectId=1347 CYP4F12

https://www.guidetopharmacology.org/GRAC/ObjectDisplayForward?objectId=1348 CYP4F22

https://www.guidetopharmacology.org/GRAC/ObjectDisplayForward?objectId=1349 CYP4V2 
https://www.guidetopharmacology.org/GRAC/ObjectDisplayForward?objectId=1350 CYP4X1

https://www.guidetopharmacology.org/GRAC/ObjectDisplayForward?objectId=1351 CYP4Z1

https://www.guidetopharmacology.org/GRAC/ObjectDisplayForward?objectId=1352 CYP5, CYP7 and CYP8 families

https://www.guidetopharmacology.org/GRAC/FamilyDisplayForward?familyId=265

Enzymes

Thromboxane-A synthase(CYP5A1)

https://www.guidetopharmacology.org/GRAC/ObjectDisplayForward?objectId=1353 Cholesterol 7 alpha-hydroxylase(CYP7A1)

https://www.guidetopharmacology.org/GRAC/ObjectDisplayForward?objectId=1354 CYP7B1

https://www.guidetopharmacology.org/GRAC/ObjectDisplayForward?objectId=1355 Prostacyclin synthase(CYP8A1)

https://www.guidetopharmacology.org/GRAC/ObjectDisplayForward?objectId=1356 CYP8B1

https://www.guidetopharmacology.org/GRAC/ObjectDisplayForward?objectId=1357

CYP11, CYP17, CYP19, CYP20 and CYP21 families

https://www.guidetopharmacology.org/GRAC/FamilyDisplayForward?familyId=266

Enzymes

Cholesterol side-chain cleavage enzyme(CYP11A1)

https://www.guidetopharmacology.org/GRAC/ObjectDisplayForward?objectId=1358 Steroid 11ß-hydroxylase(CYP11B1)

https://www.guidetopharmacology.org/GRAC/ObjectDisplayForward?objectId=1359 Aldosterone synthase(CYP11B2)

https://www.guidetopharmacology.org/GRAC/ObjectDisplayForward?objectId=1360 CYP17A1

https://www.guidetopharmacology.org/GRAC/ObjectDisplayForward?objectId=1361 Aromatase(CYP19A1)

https://www.guidetopharmacology.org/GRAC/ObjectDisplayForward?objectId=1362 CYP20A1

https://www.guidetopharmacology.org/GRAC/ObjectDisplayForward?objectId=1363 Steroid 21-hydroxylase(CYP21A2)

https://www.guidetopharmacology.org/GRAC/ObjectDisplayForward?objectId=1364

CYP24, CYP26 and CYP27 families

https://www.guidetopharmacology.org/GRAC/FamilyDisplayForward?familyId=267

Enzymes

Vitamin D3 24-hydroxylase(CYP24A1)

https://www.guidetopharmacology.org/GRAC/ObjectDisplayForward?objectId=1365 CYP26A1

https://www.guidetopharmacology.org/GRAC/ObjectDisplayForward?objectId=1366 CYP26B1

https://www.guidetopharmacology.org/GRAC/ObjectDisplayForward?objectId=1367 CYP26C1

https://www.guidetopharmacology.org/GRAC/ObjectDisplayForward?objectId=1368 Sterol 27-hydroxylase(CYP27A1)

https://www.guidetopharmacology.org/GRAC/ObjectDisplayForward?objectId=1369 25-Hydroxyvitamin D 1-alpha-hydroxylase(CYP27B1)

https://www.guidetopharmacology.org/GRAC/ObjectDisplayForward?objectId=1370 CYP27C1

https://www.guidetopharmacology.org/GRAC/ObjectDisplayForward?objectId=1371

CYP39, CYP46 and CYP51 families

https://www.guidetopharmacology.org/GRAC/FamilyDisplayForward? familyId=268

Enzymes

CYP39A1

https://www.guidetopharmacology.org/GRAC/ObjectDisplayForward?objectId=1372 Cholesterol 24-hydroxylase(CYP46A1)

https://www.guidetopharmacology.org/GRAC/ObjectDisplayForward?objectId=1373 Lanosterol 14- $\alpha$-demethylase(CYP51A1)

https://www.guidetopharmacology.org/GRAC/ObjectDisplayForward?objectId=1374

\section{References}

1. Aboraia AS, Makowski B, Bahja A, Prosser D, Brancale A, Jones G and Simons C. (2010) Synthesis and CYP24A1 inhibitory activity of (E)-2-(2-substituted benzylidene)- and 2-(2- 
substituted benzyl)-6-methoxy-tetralones. Eur J Med Chem 45: 4427-34 [PMID:20655626]

2. Agarwal V, Kommaddi RP, Valli K, Ryder D, Hyde TM, Kleinman JE, Strobel HW and Ravindranath V. (2008) Drug metabolism in human brain: high levels of cytochrome P4503A43 in brain and metabolism of anti-anxiety drug alprazolam to its active metabolite. PLOS ONE 3 : e2337 [PMID:18545703]

3. Androutsopoulos VP, Papakyriakou A, Vourloumis D and Spandidos DA. (2011) Comparative CYP1A1 and CYP1B1 substrate and inhibitor profile of dietary flavonoids. Bioorg Med Chem 19: 2842-9 [PMID:21482471]

4. Backman JT, Filppula AM, Niemi M and Neuvonen PJ. (2016) Role of Cytochrome P450 2C8 in Drug Metabolism and Interactions. Pharmacol Rev 68: 168-241 [PMID:26721703]

5. Bae SH, Kwon MJ, Choi EJ, Zheng YF, Yoon KD, Liu KH and Bae SK. (2013) Potent inhibition of cytochrome P450 2B6 by sibutramine in human liver microsomes. Chem Biol Interact 205: 11-9 [PMID:23777987]

6. Benowitz NL. (1988) Drug therapy. Pharmacologic aspects of cigarette smoking and nicotine addition. $N$ Engl J Med 319: 1318-30 [PMID:3054551]

7. Bertilsson L, Henthorn TK, Sanz E, Tybring G, Säwe J and Villén T. (1989) Importance of genetic factors in the regulation of diazepam metabolism: relationship to S-mephenytoin, but not debrisoquin, hydroxylation phenotype. Clin Pharmacol Ther 45: 348-55 [PMID:2495208]

8. Bhagwat SS, Gude C, Boswell C, Contardo N, Cohen DS, Dotson R, Mathis J, Lee W, Furness P and Zoganas H. (1992) Thromboxane receptor antagonism combined with thromboxane synthase inhibition. 4. 8-[[(4-Chlorophenyl)sulfonyl]amino]-4-(3-(3-pyridinyl) propyl)octanoic acid and analogs. J Med Chem 35: 4373-83 [PMID:1447738]

9. Bhatnagar AS, Häusler A, Schieweck K, Lang M and Bowman R. (1990) Highly selective inhibition of estrogen biosynthesis by CGS 20267, a new non-steroidal aromatase inhibitor. $J$ Steroid Biochem Mol Biol 37: 1021-7 [PMID:2149502]

10. Boezio AA, Berry L, Albrecht BK, Bauer D, Bellon SF, Bode C, Chen A, Choquette D, Dussault I and Fang $\mathrm{M}$ et al.. (2009) Discovery and optimization of potent and selective triazolopyridazine series of c-Met inhibitors. Bioorg Med Chem Lett 19: 6307-12 [PMID:19819693]

11. Boonruang S, Prakobsri K, Pouyfung P, Prasopthum A, Rongnoparut P and Sarapusit S. (2020) Structure-activity relationship and in vitro inhibition of human cytochrome CYP2A6 and CYP2A13 by flavonoids. Xenobiotica 50: 630-639 [PMID:31578905]

12. Bourrié M, Meunier V, Berger Y and Fabre G. (1996) Cytochrome P450 isoform inhibitors as a tool for the investigation of metabolic reactions catalyzed by human liver microsomes. $J$ Pharmacol Exp Ther 277: 321-32 [PMID:8613937]

13. Browne LJ, Gude C, Rodriguez H, Steele RE and Bhatnager A. (1991) Fadrozole hydrochloride: a potent, selective, nonsteroidal inhibitor of aromatase for the treatment of estrogen-dependent disease. J Med Chem 34: 725-36 [PMID:1825337]

14. Buneman P, Christie G, Davies JA, Dimitrellou R, Harding SD, Pawson AJ, Sharman JL and Wu Y. (2020) Why data citation isn't working, and what to do about it Database 2020 [PMID:32367113]

15. Bylund J, Hidestrand M, Ingelman-Sundberg M and Oliw EH. (2000) Identification of CYP4F8 in human seminal vesicles as a prominent 19-hydroxylase of prostaglandin endoperoxides. J Biol Chem 275: 21844-9 [PMID:10791960]

16. Cheng JB, Motola DL, Mangelsdorf DJ and Russell DW. (2003) De-orphanization of cytochrome P450 2R1: a microsomal vitamin D 25-hydroxilase. J Biol Chem 278: 38084-93 [PMID:12867411]

17. Chuang SS, Helvig C, Taimi M, Ramshaw HA, Collop AH, Amad M, White JA, Petkovich M, Jones G and Korczak B. (2004) CYP2U1, a novel human thymus- and brain-specific cytochrome P450, catalyzes omega- and (omega-1)-hydroxylation of fatty acids. J Biol Chem 279: 6305-14 [PMID:14660610]

18. Chung FF, Mai CW, Ng PY and Leong CO. (2016) Cytochrome P450 2W1 (CYP2W1) in Colorectal Cancers. Curr Cancer Drug Targets 16: 71-8 [PMID:26563883]

19. Corcos L, Lucas D, Le Jossic-Corcos C, Dréano Y, Simon B, Plée-Gautier E, Amet Y and Salaün JP. (2012) Human cytochrome P450 4F3: structure, functions, and prospects. Drug Metabol Drug Interact 27: 63-71 [PMID:22706230]

20. Covey DF and Hood WF. (1982) A new hypothesis based on suicide substrate inhibitor studies for the mechanism of action of aromatase. Cancer Res 42: 3327s-3333s [PMID:7083195]

21. Crosignani S, Jorand-Lebrun C, Campbell G, Prêtre A, Grippi-Vallotton T, Quattropani A, Bouscary-Desforges G, Bombrun A, Missotten M and Humbert Y et al.. (2011) Discovery of a Novel Series of CRTH2 (DP2) Receptor Antagonists Devoid of Carboxylic Acids. ACS Med Chem Lett 2: 938-42 [PMID:24900284]

22. Daly AK. (2006) Significance of the minor cytochrome P450 3A isoforms. Clin Pharmacokinet 45: 13-31 [PMID:16430309]

23. Daly AK, Rettie AE, Fowler DM and Miners JO. (2017) Pharmacogenomics of CYP2C9: Functional and Clinical Considerations. J Pers Med 8 [PMID:29283396]

24. Denton TT, Zhang X and Cashman JR. (2005) 5-substituted, 6-substituted, and unsubstituted 3- 
heteroaromatic pyridine analogues of nicotine as selective inhibitors of cytochrome P-450 2A6. J Med Chem 48: 224-39 [PMID:15634016]

25. Desta Z, Zhao X, Shin JG and Flockhart DA. (2002) Clinical significance of the cytochrome P450 2C19 genetic polymorphism. Clin Pharmacokinet 41: 913-58 [PMID:12222994]

26. Dhers L, Ducassou L, Boucher JL and Mansuy D. (2017) Cytochrome P450 2U1, a very peculiar member of the human P450s family. Cell Mol Life Sci 74: 1859-1869 [PMID:28083596]

27. Diesinger T, Buko V, Lautwein A, Dvorsky R, Belonovskaya E, Lukivskaya O, Naruta E, Kirko S, Andreev V and Buckert D et al.. (2020) Drug targeting CYP2E1 for the treatment of early-stage alcoholic steatohepatitis. PLoS One 15: e0235990 [PMID:32701948]

28. Divanovic S, Dalli J, Jorge-Nebert LF, Flick LM, Gálvez-Peralta M, Boespflug ND, Stankiewicz TE, Fitzgerald JM, Somarathna M and Karp CL et al.. (2013) Contributions of the three CYP1 monooxygenases to pro-inflammatory and inflammation-resolution lipid mediator pathways. $J$ Immunol 191: 3347-57 [PMID:23956430]

29. Dukes M, Edwards PN, Large M, Smith IK and Boyle T. (1996) The preclinical pharmacology of "Arimidex" (anastrozole; ZD1033)--a potent, selective aromatase inhibitor. J Steroid Biochem Mol Biol 58: 439-45 [PMID:8903429]

30. Durairaj P, Fan L, Machalz D, Wolber G and Bureik M. (2019) Functional characterization and mechanistic modeling of the human cytochrome P450 enzyme CYP4A22. FEBS Lett 593: 22142225 [PMID:31199497]

31. Dutheil F, Dauchy S, Diry M, Sazdovitch V, Cloarec O, Mellottée L, Bièche I, Ingelman-Sundberg M, Flinois JP and de Waziers I et al.. (2009) Xenobiotic-metabolizing enzymes and transporters in the normal human brain: regional and cellular mapping as a basis for putative roles in cerebral function. Drug Metab Dispos 37: 1528-38 [PMID:19359404]

32. Dutour R and Poirier D. (2017) Inhibitors of cytochrome P450 (CYP) 1B1. Eur J Med Chem 135 : 296-306 [PMID:28458135]

33. Edson KZ and Rettie AE. (2013) CYP4 enzymes as potential drug targets: focus on enzyme multiplicity, inducers and inhibitors, and therapeutic modulation of 20-hydroxyeicosatetraenoic acid (20-HETE) synthase and fatty acid $\omega$-hydroxylase activities. Curr Top Med Chem 13: 142940 [PMID:23688133]

34. Esperón-Moldes U, Ginarte-Val M, Rodríguez-Pazos L, Fachal L, Martín-Santiago A, Vicente A, Jiménez-Gallo D, Guillén-Navarro E, Sampol LM and González-Enseñat MA et al.. (2020) Novel CYP4F22 mutations associated with autosomal recessive congenital ichthyosis (ARCI). Study of the CYP4F22 c.1303C>T founder mutation. PLoS One 15: e0229025 [PMID:32069299]

35. Faull AW, Brewster AG, Brown GR, Smithers MJ and Jackson R. (1995) Dual-acting thromboxane receptor antagonist/synthase inhibitors: synthesis and biological properties of [2-substituted-4(3-pyridyl)-1,3-dioxan-5-yl] alkenoic acids. J Med Chem 38: 686-94 [PMID:7861416]

36. Fekry MI, Xiao Y, Berg JZ and Guengerich FP. (2019) A Role for the Orphan Human Cytochrome P450 2S1 in Polyunsaturated Fatty Acid $\omega$-1 Hydroxylation Using an Untargeted Metabolomic Approach. Drug Metab Dispos 47: 1325-1332 [PMID:31511258]

37. Feng C, Wang H, Lee M, Zhao J, Lin Z and Yang Y. (2017) Two missense mutations in CYP4F22 in autosomal recessive congenital ichthyosis. Clin Exp Dermatol 42: 98-100 [PMID:27735052]

38. Fer M, Corcos L, Dréano Y, Plée-Gautier E, Salaün JP, Berthou F and Amet Y. (2008) Cytochromes $\mathrm{P} 450$ from family 4 are the main omega hydroxylating enzymes in humans: CYP4F3B is the prominent player in PUFA metabolism. J Lipid Res 49: 2379-89 [PMID:18577768]

39. Fitzsimmons ME and Collins JM. (1997) Selective biotransformation of the human immunodeficiency virus protease inhibitor saquinavir by human small-intestinal cytochrome P4503A4: potential contribution to high first-pass metabolism. Drug Metab Dispos 25: 256-66 [PMID:9029057]

40. Flockhart DA.. Drug Interactions: Cytochrome P450 Drug Interaction Table. Indiana University School of Medicine (2007).

41. Fontana E, Dansette PM and Poli SM. (2005) Cytochrome p450 enzymes mechanism based inhibitors: common sub-structures and reactivity. Curr Drug Metab 6: 413-54 [PMID:16248836]

42. Foti RS, Rock DA, Han X, Flowers RA, Wienkers LC and Wahlstrom JL. (2012) Ligand-based design of a potent and selective inhibitor of cytochrome P450 2C19. J Med Chem 55: 1205-14 [PMID:22239545]

43. Friggeri L, Hargrove TY, Wawrzak Z, Guengerich FP and Lepesheva GI. (2019) Validation of Human Sterol 14 $\alpha$-Demethylase (CYP51) Druggability: Structure-Guided Design, Synthesis, and Evaluation of Stoichiometric, Functionally Irreversible Inhibitors. J Med Chem 62: 10391-10401 [PMID:31663733]

44. Fukami T, Nakajima M, Sakai H, McLeod HL and Yokoi T. (2006) CYP2A7 polymorphic alleles confound the genotyping of CYP2A6*4A allele. Pharmacogenomics J 6: 401-12 [PMID:16636685]

45. Furster C and Wikvall K. (1999) Identification of CYP3A4 as the major enzyme responsible for 25-hydroxylation of 5beta-cholestane-3alpha,7alpha,12alpha-triol in human liver microsomes. Biochim Biophys Acta 1437: 46-52 [PMID:9931427] 
46. Giudici D, Ornati G, Briatico G, Buzzetti F, Lombardi P and di Salle E. (1988) 6Methylenandrosta-1,4-diene-3,17-dione (FCE 24304): a new irreversible aromatase inhibitor. $J$ Steroid Biochem 30: 391-4 [PMID:3386266]

47. Gomaa MS, Bridgens CE, Veal GJ, Redfern CP, Brancale A, Armstrong JL and Simons C. (2011) Synthesis and biological evaluation of 3-(1H-imidazol- and triazol-1-yl)-2,2-dimethyl-3-[4(naphthalen-2-ylamino)phenyl]propyl derivatives as small molecule inhibitors of retinoic acid 4hydroxylase (CYP26). J Med Chem 54: 6803-11 [PMID:21838328]

48. Gorman RR, Johnson RA, Spilman CH and Aiken JW. (1983) Inhibition of platelet thromboxane A2 synthase activity by sodium 5-(3'-pyridinylmethyl)benzofuran-2-carboxylate. Prostaglandins 26: 325-42 [PMID:6316421]

49. Greenblatt DJ and Harmatz JS. (2015) Ritonavir is the best alternative to ketoconazole as an index inhibitor of cytochrome P450-3A in drug-drug interaction studies. Br J Clin Pharmacol 80: 342-50 [PMID:25923589]

50. Gresele P, Deckmyn H, Arnout J, Nenci GG and Vermylen J. (1989) Characterization of N,N'bis(3-picolyl)-4-methoxy-isophtalamide (picotamide) as a dual thromboxane synthase inhibitor/thromboxane A2 receptor antagonist in human platelets. Thromb Haemost 61: 479-84 [PMID:2552606]

51. Groarke DA, Drmota T, Bahia DS, Evans NA, Wilson S and Milligan G. (2001) Analysis of the Cterminal tail of the rat thyrotropin-releasing hormone receptor-1 in interactions and cointernalization with beta-arrestin 1-green fluorescent protein. Mol Pharmacol 59: 375-85 [PMID:11160875]

52. Gryglewski RJ, Bunting S, Moncada S, Flower RJ and Vane JR. (1976) Arterial walls are protected against deposition of platelet thrombi by a substance (prostaglandin X) which they make from prostaglandin endoperoxides. Prostaglandins 12: 685-713 [PMID:824685]

53. Gryglewski RJ, Szczeklik A, Korbut R, Swies J, Musiał J, Krzanowski M and Maga P. (1995) The mechanism of anti-thrombotic, thrombolytic and fibrinolytic actions of camonagrel--a new thromboxane synthase inhibitor. Wien Klin Wochenschr 107: 283-9 [PMID:7778318]

54. Guengerich FP and Cheng Q. (2011) Orphans in the human cytochrome P450 superfamily: approaches to discovering functions and relevance in pharmacology. Pharmacol Rev 63: 684-99 [PMID:21737533]

55. Guengerich FP, Martin MV, Beaune PH, Kremers P, Wolff T and Waxman DJ. (1986) Characterization of rat and human liver microsomal cytochrome P-450 forms involved in nifedipine oxidation, a prototype for genetic polymorphism in oxidative drug metabolism. J Biol Chem 261: 5051-60 [PMID:3514607]

56. Ha-Duong NT, Dijols S, Marques-Soares C, Minoletti C, Dansette PM and Mansuy D. (2001) Synthesis of sulfaphenazole derivatives and their use as inhibitors and tools for comparing the active sites of human liver cytochromes P450 of the 2C subfamily. J Med Chem 44: 3622-31 [PMID:11606127]

57. Haidar S, Ehmer PB, Barassin S, Batzl-Hartmann C and Hartmann RW. (2003) Effects of novel 17alpha-hydroxylase/C17, 20-lyase (P450 17, CYP 17) inhibitors on androgen biosynthesis in vitro and in vivo. J Steroid Biochem Mol Biol 84: 555-62 [PMID:12767280]

58. Handratta VD, Vasaitis TS, Njar VC, Gediya LK, Kataria R, Chopra P, Newman Jr D, Farquhar R, Guo Z and Qiu Y et al.. (2005) Novel C-17-heteroaryl steroidal CYP17 inhibitors/antiandrogens: synthesis, in vitro biological activity, pharmacokinetics, and antitumor activity in the LAPC4 human prostate cancer xenograft model. J Med Chem 48: 2972-84 [PMID:15828836]

59. Harmon SD, Fang X, Kaduce TL, Hu S, Raj Gopal V, Falck JR and Spector AA. (2006) Oxygenation of omega-3 fatty acids by human cytochrome P450 4F3B: effect on 20hydroxyeicosatetraenoic acid production. Prostaglandins Leukot Essent Fatty Acids 75: 169-77 [PMID:16820285]

60. Hatae T, Hara S, Yokoyama C, Yabuki T, Inoue H, Ullrich V and Tanabe T. (1996) Site-directed mutagenesis of human prostacyclin synthase: Alteration of Cys441 of the Cys-pocket, and Glu347 and Arg350 of the EXXR motif. FEBS Lett 389: 268-72 [PMID:8766713]

61. Hecht SS and Hoffmann D. (1988) Tobacco-specific nitrosamines, an important group of carcinogens in tobacco and tobacco smoke. Carcinogenesis 9: 875-84 [PMID:3286030]

62. Helsby NA, Ward SA, Edwards G, Howells RE and Breckenridge AM. (1990) The pharmacokinetics and activation of proguanil in man: consequences of variability in drug metabolism. Br J Clin Pharmacol 30: 593-8 [PMID:2291871]

63. Hibi S, Okamoto Y, Tagami K, Numata H, Kobayashi N, Shinoda M, Kawahara T, Harada K, Miyamoto K and Yamatsu I. (1996) Structure-activity relationships of (E)-3-(1,4benzoquinonyl)-2-[(3-pyridyl)-alkyl]-2-propenoic acid derivatives that inhibit both 5-lipoxygenase and thromboxane A2 synthetase. J Med Chem 39: 3148-57 [PMID:8759636]

64. Hiraku S, Taniguchi K, Wakitani K, Omawari N, Kira H, Miyamoto T, Okegawa T, Kawasaki A and Ujiie A. (1986) Pharmacological studies on the TXA2 synthetase inhibitor (E)-3-[p-(1Himidazol-1-ylmethyl)phenyl]-2-propenoic acid (OKY-046). Jpn J Pharmacol 41: 393-401 [PMID:3093741]

65. Ishida H, Noshiro M, Okuda K and Coon MJ. (1992) Purification and characterization of 7 alpha- 
hydroxy-4-cholesten-3-one 12 alpha-hydroxylase. J Biol Chem 267: 21319-23 [PMID:1400444]

66. Jin J, An M, Sapienza A, Aiyar N, Naselsky D, Sarau HM, Foley JJ, Salyers KL, Knight SD and Keenan RM et al.. (2008) Urotensin-II receptor antagonists: synthesis and SAR of N-cyclic azaalkyl benzamides. Bioorg Med Chem Lett 18: 3950-4 [PMID:18573659]

67. Kahraman M, Sinishtaj S, Dolan PM, Kensler TW, Peleg S, Saha U, Chuang SS, Bernstein G, Korczak B and Posner GH. (2004) Potent, selective and low-calcemic inhibitors of CYP24 hydroxylase: 24-sulfoximine analogues of the hormone 1alpha,25-dihydroxyvitamin $\mathrm{D}(3)$. J Med Chem 47: 6854-63 [PMID:15615534]

68. Khanapure SP, Garvey DS, Janero DR and Letts LG. (2007) Eicosanoids in inflammation: biosynthesis, pharmacology, and therapeutic frontiers. Curr Top Med Chem 7: 311-40 [PMID:17305573]

69. Kharasch ED, Mitchell D, Coles R and Blanco R. (2008) Rapid clinical induction of hepatic cytochrome P4502B6 activity by ritonavir. Antimicrob Agents Chemother 52: 1663-9 [PMID:18285471]

70. Kim HG, Lee HS, Jeon JS, Choi YJ, Choi YJ, Yoo SY, Kim EY, Lee K, Park I and Na M et al.. (2020) Quasi-Irreversible Inhibition of CYP2D6 by Berberine. Pharmaceutics 12 [PMID:32987920]

71. Kowalski JP, McDonald MG, Pelletier RD, Hanenberg H, Wiek C and Rettie AE. (2020) Design and Characterization of the First Selective and Potent Mechanism-Based Inhibitor of Cytochrome P450 4Z1. J Med Chem 63: 4824-4836 [PMID:32302132]

72. Kramlinger VM, Nagy LD, Fujiwara R, Johnson KM, Phan TT, Xiao Y, Enright JM, Toomey MB, Corbo JC and Guengerich FP. (2016) Human cytochrome P450 27C1 catalyzes 3,4-desaturation of retinoids. FEBS Lett 590: 1304-12 [PMID:27059013]

73. Lafite P, Dijols S, Buisson D, Macherey AC, Zeldin DC, Dansette PM and Mansuy D. (2006) Design and synthesis of selective, high-affinity inhibitors of human cytochrome P450 2J2. Bioorg Med Chem Lett 16: 2777-80 [PMID:16495056]

74. LaSala D, Shibanaka Y and Jeng AY. (2009) Coexpression of CYP11B2 or CYP11B1 with adrenodoxin and adrenodoxin reductase for assessing the potency and selectivity of aldosterone synthase inhibitors. Anal Biochem 394: 56-61 [PMID:19622340]

75. Le Quéré V, Plée-Gautier E, Potin P, Madec S and Salaün JP. (2004) Human CYP4F3s are the main catalysts in the oxidation of fatty acid epoxides. J Lipid Res 45: 1446-58 [PMID:15145985]

76. Lehmann TP, Wrzesiński T and Jagodziński PP. (2013) The effect of mitotane on viability, steroidogenesis and gene expression in NCI-H295R adrenocortical cells. Mol Med Rep 7: 893900 [PMID:23254310]

77. Lewis DF, Ito Y and Lake BG. (2009) Molecular modelling of CYP2F substrates: comparison of naphthalene metabolism by human, rat and mouse CYP2F subfamily enzymes. Drug Metabol Drug Interact 24: 229-57 [PMID:20408502]

78. Li-Hawkins J, Lund EG, Bronson AD and Russell DW. (2000) Expression cloning of an oxysterol 7alpha-hydroxylase selective for 24-hydroxycholesterol. J Biol Chem 275: 16543-9 [PMID:10748047]

79. Libè R, Fratticci A and Bertherat J. (2007) Adrenocortical cancer: pathophysiology and clinical management. Endocr Relat Cancer 14: 13-28 [PMID:17395972]

80. Lindmark B, Lundahl A, Kanebratt KP, Andersson TB and Isin EM. (2018) Human hepatocytes and cytochrome P450-selective inhibitors predict variability in human drug exposure more accurately than human recombinant P450s. Br J Pharmacol 175: 2116-2129 [PMID:29574682]

81. Liu J, Taylor SF, Dupart PS, Arnold CL, Sridhar J, Jiang Q, Wang Y, Skripnikova EV, Zhao M and Foroozesh M. (2013) Pyranoflavones: a group of small-molecule probes for exploring the active site cavities of cytochrome P450 enzymes 1A1, 1A2, and 1B1. J Med Chem 56: 4082-92 [PMID:23600958]

82. Llerena A, Dorado P and Peñas-Lledó EM. (2009) Pharmacogenetics of debrisoquine and its use as a marker for CYP2D6 hydroxylation capacity. Pharmacogenomics 10: 17-28 [PMID:19102711]

83. Lu WJ, Desta Z and Flockhart DA. (2012) Tamoxifen metabolites as active inhibitors of aromatase in the treatment of breast cancer. Breast Cancer Res Treat 131: 473-81 [PMID:21390495]

84. Lu WJ, Xu C, Pei Z, Mayhoub AS, Cushman M and Flockhart DA. (2012) The tamoxifen metabolite norendoxifen is a potent and selective inhibitor of aromatase (CYP19) and a potential lead compound for novel therapeutic agents. Breast Cancer Res Treat 133: 99-109 [PMID:21814747]

85. Lv W, Liu J, Lu D, Flockhart DA and Cushman M. (2013) Synthesis of mixed (E,Z)-, (E)-, and (Z)norendoxifen with dual aromatase inhibitory and estrogen receptor modulatory activities. J Med Chem 56: 4611-8 [PMID:23731360]

86. Mahli A, Erwin Thasler W and Hellerbrand C. (2019) Establishment of a p-nitrophenol oxidationbased assay for the analysis of CYP2E1 activity in intact hepatocytes in vitro. Toxicol Mech Methods 29: 219-223 [PMID:30380359]

87. Mayhoub AS, Marler L, Kondratyuk TP, Park EJ, Pezzuto JM and Cushman M. (2012) Optimization of the aromatase inhibitory activities of pyridylthiazole analogues of resveratrol. 
Bioorg Med Chem 20: 2427-34 [PMID:22386564]

88. McFadyen MC, McLeod HL, Jackson FC, Melvin WT, Doehmer J and Murray GI. (2001)

Cytochrome P450 CYP1B1 protein expression: a novel mechanism of anticancer drug resistance. Biochem Pharmacol 62: 207-12 [PMID:11389879]

89. Metcalf B, Chuang C, Dufu K, Patel MP, Silva-Garcia A, Johnson C, Lu Q, Partridge JR, Patskovska L and Patskovsky Y et al.. (2017) Discovery of GBT440, an Orally Bioavailable RState Stabilizer of Sickle Cell Hemoglobin. ACS Med Chem Lett 8: 321-326 [PMID:28337324]

90. Miller EJ, Jecs E, Truax VM, Katzman BM, Tahirovic YA, Wilson RJ, Kuo KM, Kim MB, Nguyen HH and Saindane MT et al.. (2018) Discovery of Tetrahydroisoquinoline-Containing CXCR4 Antagonists with Improved in Vitro ADMET Properties. J Med Chem 61: 946-979 [PMID:29350534]

91. Miners JO, Smith KJ, Robson RA, McManus ME, Veronese ME and Birkett DJ. (1988) Tolbutamide hydroxylation by human liver microsomes. Kinetic characterisation and relationship to other cytochrome P-450 dependent xenobiotic oxidations. Biochem Pharmacol 37: 1137-44 [PMID:3355588]

92. Mizukami Y, Sumimoto H, Isobe R and Minakami S. (1993) Omega-hydroxylation of lipoxin B4 by human neutrophil microsomes: identification of omega-hydroxy metabolite of lipoxin B4 and catalysis by leukotriene B4 omega-hydroxylase (cytochrome P-450LTB omega). Biochim Biophys Acta 1168: 87-93 [PMID:8389204]

93. Nakajima M, Kuroiwa Y and Yokoi T. (2002) Interindividual differences in nicotine metabolism and genetic polymorphisms of human CYP2A6. Drug Metab Rev 34: 865-77 [PMID:12487152]

94. Nakano M, Kelly EJ and Rettie AE. (2009) Expression and characterization of CYP4V2 as a fatty acid omega-hydroxylase. Drug Metab Dispos 37: 2119-22 [PMID:19661213]

95. Nilsson T, Ivanov IV and Oliw EH. (2010) LC-MS/MS analysis of epoxyalcohols and epoxides of arachidonic acid and their oxygenation by recombinant CYP4F8 and CYP4F22. Arch Biochem Biophys 494: 64-71 [PMID:19919823]

96. Nishi T, Kondo S, Miyamoto M, Watanabe S, Hasegawa S, Kondo S, Yano J, Watanabe E, Ishi T and Yoshikawa M et al.. (2020) Soticlestat, a novel cholesterol 24-hydroxylase inhibitor shows a therapeutic potential for neural hyperexcitation in mice. Sci Rep 10: 17081 [PMID:33051477]

97. No authors listed. (2004) Natalizumab: AN 100226, anti-4alpha integrin monoclonal antibody. Drugs R D 5: 102-7 [PMID:15293871]

98. Nohara T, Ohno Y and Kihara A. (2021) Impaired production of the skin barrier lipid acylceramide by CYP4F22 ichthyosis mutations. J Dermatol Sci 101: 69-71 [PMID:33067036]

99. Noshiro M and Okuda K. (1990) Molecular cloning and sequence analysis of cDNA encoding human cholesterol 7 alpha-hydroxylase. FEBS Lett 268: 137-40 [PMID:2384150]

100. Ohno Y, Nakamichi S, Ohkuni A, Kamiyama N, Naoe A, Tsujimura H, Yokose U, Sugiura K, Ishikawa J and Akiyama $\mathrm{M}$ et al.. (2015) Essential role of the cytochrome P450 CYP4F22 in the production of acylceramide, the key lipid for skin permeability barrier formation. Proc Natl Acad Sci U S A 112: 7707-12 [PMID:26056268]

101. Orr ST, Ripp SL, Ballard TE, Henderson JL, Scott DO, Obach RS, Sun H and Kalgutkar AS. (2012) Mechanism-based inactivation (MBI) of cytochrome P450 enzymes: structure-activity relationships and discovery strategies to mitigate drug-drug interaction risks. J Med Chem 55: 4896-933 [PMID:22409598]

102. Pan Y and Ong EC. (2017) Cytochrome P450 2W1 (CYP2W1) - ready for use as the biomarker and drug target for cancer? Xenobiotica 47: 923-932 [PMID:27690753]

103. Payne EJ, Ingley E, Dick IM, Wilson SG, Bond CS and Prince RL. (2009) In vitro kinetic properties of the Thr201Met variant of human aromatase gene CYP19A1: functional responses to substrate and product inhibition and enzyme inhibitors. J Clin Endocrinol Metab 94: 29983002 [PMID:19470632]

104. Pelkonen O, Rautio A, Raunio H and Pasanen M. (2000) CYP2A6: a human coumarin 7hydroxylase. Toxicology 144: 139-47 [PMID:10781881]

105. Peng CC, Rushmore T, Crouch GJ and Jones JP. (2008) Modeling and synthesis of novel tightbinding inhibitors of cytochrome P450 2C9. Bioorg Med Chem 16: 4064-74 [PMID:18255300]

106. Poleggi A, van der Lee S, Capellari S, Puopolo M, Ladogana A, De Pascali E, Lia D, Formato A, Bartoletti-Stella A and Parchi P et al.. (2018) Age at onset of genetic (E200K) and sporadic Creutzfeldt-Jakob diseases is modulated by the CYP4X1 gene.J Neurol Neurosurg Psychiatry 89: 1243-1249 [PMID:30032116]

107. Posner GH, Helvig C, Cuerrier D, Collop D, Kharebov A, Ryder K, Epps T and Petkovich M. (2010) Vitamin D analogues targeting CYP24 in chronic kidney disease. J Steroid Biochem Mol Biol 121: 13-9 [PMID:20347976]

108. Potter GA, Barrie SE, Jarman M and Rowlands MG. (1995) Novel steroidal inhibitors of human cytochrome P45017 alpha (17 alpha-hydroxylase-C17,20-lyase): potential agents for the treatment of prostatic cancer. J Med Chem 38: 2463-71 [PMID:7608911]

109. Qi X, Dou T, Wang Z, Wu J, Yang L, Zeng S, Deng M, Lü M and Liang S. (2019) Inhibition of human cytochrome P450 2A6 by 7-hydroxycoumarin analogues: Analysis of the structure-activity 
relationship and isoform selectivity. Eur J Pharm Sci 136: 104944 [PMID:31163215]

110. Randall MJ, Parry MJ, Hawkeswood E, Cross PE and Dickinson RP. (1981) UK-37, 248, a novel, selective thromboxane synthetase inhibitor with platelet anti-aggregatory and anti-thrombotic activity. Thromb Res 23: 145-62 [PMID:6795753]

111. Rose KA, Stapleton G, Dott K, Kieny MP, Best R, Schwarz M, Russell DW, Björkhem I, Seckl J and Lathe R. (1997) Cyp7b, a novel brain cytochrome P450, catalyzes the synthesis of neurosteroids 7alpha-hydroxy dehydroepiandrosterone and 7alpha-hydroxy pregnenolone. Proc Natl Acad Sci USA 94: 4925-30 [PMID:9144166]

112. Rotstein DM, Kertesz DJ, Walker KA and Swinney DC. (1992) Stereoisomers of ketoconazole: preparation and biological activity. J Med Chem 35: 2818-25 [PMID:1495014]

113. Sevrioukova IF and Poulos TL. (2015) Current Approaches for Investigating and Predicting Cytochrome P450 3A4-Ligand Interactions. Adv Exp Med Biol 851: 83-105 [PMID:26002732]

114. Shahrokh K, Cheatham 3rd TE and Yost GS. (2012) Conformational dynamics of CYP3A4 demonstrate the important role of Arg212 coupled with the opening of ingress, egress and solvent channels to dehydrogenation of 4-hydroxy-tamoxifen. Biochim Biophys Acta 1820: 1605 17 [PMID:22677141]

115. Shak S, Reich NO, Goldstein IM and Ortiz de Montellano PR. (1985) Leukotriene B4 omegahydroxylase in human polymorphonuclear leukocytes. Suicidal inactivation by acetylenic fatty acids. J Biol Chem 260: 13023-8 [PMID:2997155]

116. Siller M, Goyal S, Yoshimoto FK, Xiao Y, Wei S and Guengerich FP. (2014) Oxidation of endogenous $\mathrm{N}$-arachidonoylserotonin by human cytochrome P450 2U1. J Biol Chem 289: 1047687 [PMID:24563460]

117. Solanki M, Pointon A, Jones B and Herbert K. (2018) Cytochrome P450 2J2: Potential Role in Drug Metabolism and Cardiotoxicity. Drug Metab Dispos 46: 1053-1065 [PMID:29695613]

118. Song WK, Clouston $P$ and MacLaren RE. (2019) Presence of corneal crystals confirms an unusual presentation of Bietti's retinal dystrophy. Ophthalmic Genet 40: 461-465 [PMID:31638456]

119. Sontag TJ and Parker RS. (2002) Cytochrome P450 omega-hydroxylase pathway of tocopherol catabolism. Novel mechanism of regulation of vitamin E status. J Biol Chem 277: 25290-6 [PMID:11997390]

120. Sridhar J, Goyal N, Liu J and Foroozesh M. (2017) Review of Ligand Specificity Factors for CYP1A Subfamily Enzymes from Molecular Modeling Studies Reported to-Date. Molecules 22 [PMID:28698457]

121. Stark K, Dostalek M and Guengerich FP. (2008) Expression and purification of orphan cytochrome P450 4X1 and oxidation of anandamide. FEBS J 275: 3706-17 [PMID:18549450]

122. Strobl GR, von Kruedener S, Stöckigt J, Guengerich FP and Wolff T. (1993) Development of a pharmacophore for inhibition of human liver cytochrome P-450 2D6: molecular modeling and inhibition studies. J Med Chem 36: 1136-45 [PMID:8487254]

123. Su T, Bao Z, Zhang QY, Smith TJ, Hong JY and Ding X. (2000) Human cytochrome P450 CYP2A13: predominant expression in the respiratory tract and its high efficiency metabolic activation of a tobacco-specific carcinogen, 4-(methylnitrosamino)-1-(3-pyridyl)-1-butanone. Cancer Res 60: 5074-9 [PMID:11016631]

124. Sykes MJ, McKinnon RA and Miners JO. (2008) Prediction of metabolism by cytochrome P450 2C9: alignment and docking studies of a validated database of substrates. J Med Chem 51: 78091 [PMID:18237107]

125. Taimi M, Helvig C, Wisniewski J, Ramshaw H, White J, Amad M, Korczak B and Petkovich M. (2004) A novel human cytochrome P450, CYP26C1, involved in metabolism of 9-cis and all-trans isomers of retinoic acid. $J$ Biol Chem 279: 77-85 [PMID:14532297]

126. Tani N, Juvonen RO, Raunio H, Fashe M, Leppänen J, Zhao B, Tyndale RF and Rahnasto-Rilla M. (2014) Rational design of novel CYP2A6 inhibitors. Bioorg Med Chem 22: 6655-64 [PMID:25458499]

127. Thatcher JE, Buttrick B, Shaffer SA, Shimshoni JA, Goodlett DR, Nelson WL and Isoherranen N. (2011) Substrate specificity and ligand interactions of CYP26A1, the human liver retinoic acid hydroxylase. Mol Pharmacol 80: 228-39 [PMID:21521770]

128. Thesseling FA, Hutter MC, Wiek C, Kowalski JP, Rettie AE and Girhard M. (2020) Novel insights into oxidation of fatty acids and fatty alcohols by cytochrome P450 monooxygenase CYP4B1. Arch Biochem Biophys 679: 108216 [PMID:31801692]

129. Turpeinen M and Zanger UM. (2012) Cytochrome P450 2B6: function, genetics, and clinical relevance. Drug Metabol Drug Interact 27: 185-97 [PMID:23152403]

130. Vasiliou V and Gonzalez FJ. (2008) Role of CYP1B1 in glaucoma. Annu Rev Pharmacol Toxicol 48: 333-58 [PMID:17914928]

131. von Moltke LL, Greenblatt DJ, Granda BW, Giancarlo GM, Duan SX, Daily JP, Harmatz JS and Shader RI. (2001) Inhibition of human cytochrome P450 isoforms by nonnucleoside reverse transcriptase inhibitors. J Clin Pharmacol 41: 85-91 [PMID:11225565]

132. von Moltke LL, Greenblatt DJ, Granda BW, Grassi JM, Schmider J, Harmatz JS and Shader RI. 
(1999) Nefazodone, meta-chlorophenylpiperazine, and their metabolites in vitro: cytochromes mediating transformation, and P450-3A4 inhibitory actions. Psychopharmacology (Berl.) 145: 113-22 [PMID:10445380]

133. Walker KA, Kertesz DJ, Rotstein DM, Swinney DC, Berry PW, So OY, Webb AS, Watson DM, Mak AY and Burton PM et al.. (1993) Selective inhibition of mammalian lanosterol 14 alphademethylase: a possible strategy for cholesterol lowering. J Med Chem 36: 2235-7 [PMID:8340925]

134. Walsky RL and Obach RS. (2007) A comparison of 2-phenyl-2-(1-piperidinyl)propane (ppp), 1,1',1'-phosphinothioylidynetrisaziridine (thioTEPA), clopidogrel, and ticlopidine as selective inactivators of human cytochrome P450 2B6. Drug Metab Dispos 35: 2053-9 [PMID:17682072]

135. Watanabe H, Yamaori S, Kamijo S, Aikawa K and Ohmori S. (2020) In Vitro Inhibitory Effects of Sesamin on CYP4F2 Activity. Biol Pharm Bull 43: 688-692 [PMID:32238710]

136. Williams JA, Ring BJ, Cantrell VE, Jones DR, Eckstein J, Ruterbories K, Hamman MA, Hall SD and Wrighton SA. (2002) Comparative metabolic capabilities of CYP3A4, CYP3A5, and CYP3A7. Drug Metab Dispos 30: 883-91 [PMID:12124305]

137. Williams PA, Cosme J, Vinkovic DM, Ward A, Angove HC, Day PJ, Vonrhein C, Tickle IJ and Jhoti H. (2004) Crystal structures of human cytochrome P450 3A4 bound to metyrapone and progesterone. Science 305: 683-6 [PMID:15256616]

138. Wittman M, Carboni J, Attar R, Balasubramanian B, Balimane P, Brassil P, Beaulieu F, Chang C, Clarke W and Dell J et al.. (2005) Discovery of a (1H-benzoimidazol-2-yl)-1H-pyridin-2-one (BMS536924 ) inhibitor of insulin-like growth factor I receptor kinase with in vivo antitumor activity. $J$ Med Chem 48: 5639-43 [PMID:16134929]

139. Wu S, Moomaw CR, Tomer KB, Falck JR and Zeldin DC. (1996) Molecular cloning and expression of CYP2J2, a human cytochrome P450 arachidonic acid epoxygenase highly expressed in heart. J Biol Chem 271: 3460-8 [PMID:8631948]

140. Wu Z, Lee D, Joo J, Shin JH, Kang W, Oh S, Lee DY, Lee SJ, Yea SS and Lee HS et al.. (2013) CYP2J2 and CYP2C19 are the major enzymes responsible for metabolism of albendazole and fenbendazole in human liver microsomes and recombinant P450 assay systems. Antimicrob Agents Chemother 57: 5448-56 [PMID:23959307]

141. Xu S, Ren Z, Wang Y, Ding X and Jiang Y. (2014) Preferential expression of cytochrome CYP CYP2R1 but not CYP1B1 in human cord blood hematopoietic stem and progenitor cells. Acta Pharm Sin B 4: 464-9 [PMID:26579418]

142. Yamaori S, Araki N, Shionoiri M, Ikehata K, Kamijo S, Ohmori S and Watanabe K. (2018) A Specific Probe Substrate for Evaluation of CYP4A11 Activity in Human Tissue Microsomes and a Highly Selective CYP4A11 Inhibitor: Luciferin-4A and Epalrestat. J Pharmacol Exp Ther 366: 446-457 [PMID:29976573]

143. Yan P, Eng OC and Yu CJ. (2018) A Review on the Expression and Metabolic Features of Orphan Human Cytochrome P450 2S1 (CYP2S1). Curr Drug Metab 19: 917-929 [PMID:29804525]

144. Yano JK, Denton TT, Cerny MA, Zhang X, Johnson EF and Cashman JR. (2006) Synthetic inhibitors of cytochrome P-450 2A6: inhibitory activity, difference spectra, mechanism of inhibition, and protein cocrystallization. J Med Chem 49: 6987-7001 [PMID:17125252]

145. Yeo KR and Yeo WW. (2001) Inhibitory effects of verapamil and diltiazem on simvastatin metabolism in human liver microsomes. Br J Clin Pharmacol 51: 461-70 [PMID:11422004]

146. Yin L, Hu Q, Emmerich J, Lo MM, Metzger E, Ali A and Hartmann RW. (2014) Novel pyridyl- or isoquinolinyl-substituted indolines and indoles as potent and selective aldosterone synthase inhibitors. J Med Chem 57: 5179-89 [PMID:24899257]

147. Zanger UM and Schwab M. (2013) Cytochrome P450 enzymes in drug metabolism: regulation of gene expression, enzyme activities, and impact of genetic variation. Pharmacol Ther 138: 10341 [PMID:23333322]

148. Zeldin DC, DuBois RN, Falck JR and Capdevila JH. (1995) Molecular cloning, expression and characterization of an endogenous human cytochrome P450 arachidonic acid epoxygenase isoform. Arch Biochem Biophys 322: 76-86 [PMID:7574697]

149. Zhang JE, Klein K, Jorgensen AL, Francis B, Alfirevic A, Bourgeois S, Deloukas P, Zanger UM and Pirmohamed M. (2017) Effect of Genetic Variability in the CYP4F2, CYP4F11, and CYP4F12 Genes on Liver mRNA Levels and Warfarin Response. Front Pharmacol 8: 323 [PMID:28620303]

150. Zhou SF. (2008) Drugs behave as substrates, inhibitors and inducers of human cytochrome P450 3A4. Curr Drug Metab 9: 310-22 [PMID:18473749]

151. Zimmer C, Hafner M, Zender M, Ammann D, Hartmann RW and Vock CA. (2011) N-(Pyridin-3yl)benzamides as selective inhibitors of human aldosterone synthase (CYP11B2). Bioorg Med Chem Lett 21: 186-90 [PMID:21129965] 